\title{
National identity and stereotypes of Poles and Germans among rural youth in Opole Silesia
}

\author{
Katarzyna Mazur \\ kasia.mazur1@gmail.com
}

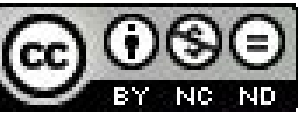

\begin{abstract}
In Opole Silesia there live a combination of people describing themselves as Poles, Germans and Silesians. Young people there have to deal with that mix, being influenced by such forces as globalization. The purpose of this research was to discover how youth feel and understand their nationality and what stereotypes they share. The analysis consisted of several tasks. Students had to describe themselves by national and ethnic categories. They were asked how they felt about Germans and which stereotypes they found to be true or false. The paper includes analysis from earlier research on this topic.
\end{abstract}

Keywords: nationality, stereotype, identity, Silesia, Poles, Germans, social distance.

\section{Introduction}

Opole Region is specific when we look at it through the prism of its inhabitants national identity. It still happens that people who speak Polish in the street, use German at home. Some of my peers from primary school used a term "You" in reference to Poles and now they say "They" about Germans, some - on the contrary - now claim German nationality although several years ago they claimed the opposite. It is quite common in the Opole Region to have dual citizenship. A lot of families have relatives on the other side of a border. When entering some municipalities there are bilingual signs. What decides people about being Pole or German...? Are Poles from the Opole Region the same as Poles from Greater Poland? What do Opole Region dwellers think about themselves and others?

\section{Terms "national identity" and "ethnic identity"}

Nation and following it national identity came to into being quite recently, only in the XIX century. Earlier people described themselves as members of a family, tribe, caste, or religious group. About the term nationality E. Kedourie, lecturer of politics and history at LSE, says: "Nationalism is a doctrine invented in Europe at the beginning of the nineteenth 
century (...). Briefly, the doctrine holds that humanity is naturally divided into nations, that nations are known by certain characteristics which can be ascertained, and the only legitimate type of government is national self-government" (Kedourie 1985, p. 9). It seems to us that this definition is a bit ironic pointing to some artificiality in the division of mankind into nations. It is said that "nation" is a European invention, so not universal, human-wide, which could, but does not have to, result in difficulties in describing by national categories.

It is not hard to see elements genetically connected with nineteenth century history and ideas in the definition by A. Smith, also an LSE lecturer: "national identity involves some sense of political community, however tenuous. A political community in turn implies at least some common institutions and a single code of rights and duties for all the members of the community. It also suggests definite social space, a fairly well demarcated and bounded territory, with which the members identify and to which they feel they belong (Smith 1993, p. 9).

Let us focus on a term which intuitively seems to be similar - category of ethnic identity (Chandra 2005, p. 6):

- $\quad$ According to M. Weber "ethnic groups are those human groups that entertain a subjective belief in their common descent because of similarities of physical type or of customs or both, or because of memories of colonization or migration; this belief must be important for the propagation of group formation; conversely, it does not matter whether or not an objective blood relationship exists" (Chandra 2005, p. 6).

- D. Horowitz claims that: "Ethnicity is based on a myth of collective ancestry, which usually carries with it traits believed to be innate. Some notion of ascription, however diluted, and affinity deriving from it are inseparable from the concept of ethnicity" (Chandra 2005, p. 6).

- J.D. Fearon says that ethnic identity consists of "descent", consciousness of being a member, having cultural features which distinguish the group and "are valued by a majority of members", "the group has or remembers a homeland" and "shared history" (Chandra 2005, p. 6).

- According to A. Smith an ethnic group is, "a named human population with myths of common ancestry, shared historical memories, one or more elements of a common culture, a link with a homeland and a sense of solidarity" (Chandra 2005, p. 6). 
Summing up, ethnic identity is combined with elements of biological and geographical descent, common history, traditions, values, norms, shared physical or psychological traits, sense of commonwealth. It should be pointed out that possession of all those elements is not necessary.

\section{Globalization and regionalization. Heimat}

It is impossible to consider the national identity question without a glance at present social and political trends.

Globalization is a very wide term. Stanford Encyclopedia of Philosophy specifies few aspects of it in reference to social sciences:

"First, contemporary analysts associate globalization with deterritorialization, according to which a growing variety of social activities takes place irrespective of the geographical location of participants (...). Second, recent theorists conceive of globalization as linked to the growth of social interconnectedness across existing geographical and political boundaries. In this view, deterritorialization is a crucial facet of globalization (...). Third, globalization must also include reference to the speed or velocity of social activity" (Scheuerman 2008). Fruits of globalization materialize in a wide palette of manners: from the equipment of a local shop to free time activity. With the rise of unification, a need to differentiate increases. Thereby globalization is followed by a process of totally converse direction - regionalism.

"Like a region, regionalism is connected with a particular territory and is differently defined. Traditionally by regionalism we mean every variability treated as differences between people, their appearance, traditions, customs and habitats - those features which define a given type of culture, usually one which roots deeply in the past. So in traditional meaning regionalism is historically determined and defines such qualities as: ethnicity, folklore, locality. Regionalism is undoubtedly an axiological category which - over centuries - formed the determinants of a region. Nowadays because of globalization these traditional determinants are somehow modified and get effaced" (Sala 2005, p. 2).

It seems that to explain the specifics of the Opole Silesia and its inhabitants identity is the idea of Heimat. This word exists only in German and is hard to translate, because it is not motherland or native land. The German word for motherland is Vaterland. Heimat is a very emotionally tinged term. It is related to a place where a man is "at home", where he was brought up and where he entered maturity. The extent of Heimat is very narrow - it is as much as a man can see from his doorstep: "There where I was born - it is motherland. For me motherland is a birthplace, family, graveyard, this is my motherland. In Popielów I would be 
a stranger. My motherland is my dear land, where the sun shines, where I met God... I speak Polish! [laugh]" (Berlińska 1999, p. 276).

It is not only a geographical space but also people, language, customs, norms. Silesian Heimat is composed of garden gnomes, J. Eichendorff's poems which often became folksongs, local dialect, kroszonki (decorated Easter eggs) and still vivid bear-leading in carnival, but also bilingual boards and monuments for victims of both world wars or the sounds at festivals Heimatmelodie.

"Europe now numbers forty three states, soon it could be a few more or a few less and in many there is a political trading of homelands. Europe has forty three states and in them, counting generously, maybe one hundred and thirty historically created regions. How many homelands has Europe, how many homelands does Europe allow to exist. Assurances admitted by philanthropists are insincere that the whole humanity is a homeland for them and formal rhetoric announcing that Europe itself is the biggest little motherland for Europeans is idle prattle" (Gauss 2008, p. 67). Slogans invoking building Europe of motherlands or a Europe of genetically defined regions is tension coming from the concurrent drive to unification and differentiation. Unity in variability is fragile unity.

\section{"They" stereotypes: origin and functions}

"To avoid conflicts, at the beginning we underline that a stranger is not just an unknown person; a person who we do not exactly know well or do not know at all or have even never heard about. The opposite fits better description: a characteristic feature of strangers is that they are known very well" (Bauman 1996, p. 61). Let us assume that the social world consists of "We" and "They", so these "They" are needed to define the limits and characteristics of "We". M. Douglas, social anthropologist, indicates that cultivating differences is so difficult because they are often not natural, and at the same time they are necessary to make it possible to convey the understanding to the world of humans (Bauman 1996, p. 63). The problem appears when someone is at the same time in two groups or does not belong to either. In an interesting "Me" context you can be a Pole or German, but can it be both at the same time? How do we consider those, who determine themselves as Silesians, but do not feel a sense of belonging to any national "We"?

An idea to place those who are "undecided", making a categorization problem, is a conception of A. Schütz. He suggested specifying social distance with a line whose end is "Me". According to the proximity and intensity of relation we put people on the line. These will be our contemporaries. Naturally, the nearest are those who we know directly, meet often 
and who have a significant influence on us, further away are those we encounter only in certain circumstances (dentist, lecturer or salesman), further away still are those who "are only of the same some human types (elders, Ethiopians, Jews, Latinos, rich men, football hooligans, soldiers, bureaucrats, etc.)” (Bauman 1996, p. 46). But we have to put our ancestors and relatives somewhere. "There are two types of proximity: spiritual and physical but they do not have to be mutually exclusive (...). Spiritual or moral proximity expressed in our skillfulness (and willingness) at experiencing union of feelings, which means that we regard other people as similar to us: they have their own purpose and rights to achieve them, similar to our emotions and similar to us, tendency to experience pleasure and pain" (Bauman 1996, p. 46) It is this spiritual proximity which is the major strength of a team. It is not important, whether our consideration of "Ours" as similar to us and foreigners as different, is true, as is shown in the experiment of M. Sheriff (1954) made on two initially dissimilar groups of boys.

Z. Bauman lists four ways of coping with foreigners who came too close. The first and the most radical form is harassment, the purpose of which is physical destruction. However, as he says usually people decide on less severe solutions, such as territorial or spiritual separation (or both)-which is, as it is easy to notice, the second degree of proximity. If separation is impossible it may occur in a different kind of segregation (e.g. because of the garment, residence district), on which is based the exclusion. For E. Goffman finally points to the civic insensitivity, consisting of the ordinarily excluded foreigner, on inconsequence that we are not interested in them. As he writes "annoying curiosity of the other disappears, but also together with it sympathy and readiness to help" (Bauman 1996, p. 75).

We define stereotype simply as a scheme of any group, its characteristic. Its essence is a conclusion about features and predicting behaviour on the criterion of belonging to the group. Contemporarily it is considered that stereotypes generate not opinions but rather hypotheses, which are often confirmed due to targeted observations (Weigl 1999, p. 13-20).

Among the theories trying to explain the roots of stereotypes is social identity theory. It appeals to the categorization mechanism as a natural mental function. It works like this: when we meet a new person, we get a set of information about him. We explore our resources to find a scheme of where he fits and then we determine other traits, and then we allocate meanings to behaviour and prognosticate latter actions.

H. Tajfel, a psychologist, claims that when categorization is added to observation, people differing about certain trait leads to double consequences: "(1) rise of observed intercategorial differences and (2) decrease of observed intracategorial differences" 
(Wojciszke 2002, p. 72). That means that "They" are not only different from us, but also "They are all the same". When one of "Them" behaves differently than we expect, we perceive him (or her) as an exception.

"Chlewiński, when describing stereotypes, lists some its traits, i.a.:

- cognitive character of the stereotype - poverty of content, reduction, closure,

- strong affective tone (emotions are a kind of durable sign for categories content),

- little variance of specimens inside category (...),

- subjective certainty about stereotype content,

- durability caused by active defense against change of stereotype.

Kurcz points out three similar features of stereotypes: reducing character, overgeneralization of content and stiffness and resistance to change" (Weigl 1999, p. 13-17).

B. Weigl lists such functions of stereotypes:

- being a simplified map of social world,

- economizing cognition,

- selection and reduction of overflow of information,

- allowing prognoses of observed objects actions,

- completing deficit of information,

- they are useful to social comparisons,

- they help in self-justifying, justifying of own group and social system (Weigl 1999, p. 17-18).

\section{Review of researches}

B. Weigl carried several researches on stereotypes and prejudices among children and youth. I will cite only some results (Weigl 1999):

- Research on seven-year-old pupils in Opole voivodship. Children were asked to evaluate some nationalities on four dimensions: bad-good, lazy-studious, lyingreliable, dirty-clean. In every respect children scored Poles higher than Germans.

- Research on pupil form $1^{\text {st }}-4^{\text {th }}$ grade done with the same method. Results were similar. Research was made in Opole.

- Research was made on fifteen year old pupils of vocational schools from South Poland. The teenagers were asked to rate mates of different nationalities with whom they would like to camp during the Youth Meeting. Another task was to estimate the campus area they would like to grant each nationality. Students more 
preferably chose Poles than Germans, average territory they gave Poles was almost twice as big as given to Germans.

These results are not surprising considering the presented theories, although they do not take into account such factors as national identity which - especially in the Opole region, is not unambiguous.

In 1990 and 1993 D. Berlińska did research on national identification and Silesian ethnic identity. They were mostly structured interviews. "Almost $40 \%$ of the Silesians declaring Polish identity had a spouse from an immigrant family. Polish preference declares most frequently people under 40 years old (51.7\%) with vocational or secondary education (65.7\%), qualified or intellectual workers, while German preference chose mostly people over 56 years old $(72.2 \%)$ with primary or vocational education, retirees and pensioners. The population of Silesians manifesting German identity did not increase. It could be result of persistent fears of intolerance. We can realistically estimate that social base for the German minority movement in Opole Silesia is about 37-40 year old Silesians" (Berlińska 1999, p. 327).

Among the older generation Silesian identification dominated: "I said, I'm neither German, nor a Pole, I am me and totally Silesian” (Berlińska 1999, p. 305). Younger respondents say for e.g. "I can't hide, I feel Silesian. I don't feel German because I have Polish citizenship and there is nothing to talk about, I have Polish nationality too (...). I feel Pole because I live in Poland" (Brelińska 1999, p. 305). Another approach is to avoid national designation and point out that the Europe-uniting process makes, or will make categorization unnecessary in the future.

\section{Questions and hypothesis}

As it was mentioned above the subject of research consists of two constituents. The first one is the national identity of rural youth in Opole Silesia. The other is the Pole and German stereotype connected with that identity. I took four questions into consideration:

1. How do youth describe their national identity?

2. What influences their national identity?

3. What is the Pole stereotype like?

4. What is the German stereotype like?

I assumed that the group would not be homogenous in perceiving the national and ethnic identity. There would be people who characterized themselves only as Poles, Germans 
or Silesians, and people whose identity is a mixture of these categories and those who use two or three categories.

I presumed that identity was influenced by family, especially parents. According to my thesis that pupils whose parents belong to the German Minority, work or used to work in Germany would have a tendency to perceive themselves as "German". I intended to verify such factors as having family in Germany or using German language at home.

I thought that the answer to the last questions would be dependent on national identity. Moreover I supposed the more someone feels Pole the better is his opinion about Poles and worse about Germans. And vice versa - the more someone identifies as German the better is his opinion about Germans and worse about Poles.

\section{Method}

Research was carried out in the High School in Turawa in classes 1-3. I received 75 correctly filled in questionnaires. In a few surveys single answers were missing which was obviously taken into consideration in statistical analysis. 27 students were first graders, 18 second and 30 third. There were 36 boys (48\%) and 39 girls.

I constructed a questionnaire of 6 tasks.

The first task related to identity. I used a millimeter scale. Respondents were asked to place their position in three dimensions: "Pole"- "not-Pole", "German"- "not-German", "Silesian"- "not-Silesian". I wanted to avoid an uninterpretable point in the middle of the scale with ends "Pole" - "German" and give participants a chance to describe themselves by more than one category. They had an opportunity to show how much they feel Poles, Germans and Silesians. $0 \mathrm{~mm}$ was ascribed to "Pole", "German" and "Silesian" and $100 \mathrm{~mm}$ to "not-Pole", "not-German" and "not-Silesian". To simplify analysis I divided the scale into parts, of which only two were significant for me:

0-20 mm "definitely" Pole/ German/ Silesian,

81-100mm "not-Pole"/ "not- German"/ "not-Silesian".

The second task- clock- method- I took from works of B. Weigl (Weigl 1990). Its purpose is to measure the social distance. Students were asked to grant a place on a campsite to a peer from Germany. The campsite was a circle divided into 12 segments. There was the respondent's tent in one section. In the original version the maximal distance equate 6 and minimal 1. During the research it turned out that the scale was too narrow. Some of the students wanted to invite the mate to their section and some asked whether they could put him 
outside. Due to this I decided to widen the scale so I inserted a rank 0 when mates tent was in respondent's place and a rank 7 when it was outside the campsite.

Tasks three and four I devoted to characterize respectively "average Pole" and "average German". I used a ten-point scale based on semantic differentials. The scale contained 30 positions.

The demographic questions - fifth - concerned as follows: parents belonging to the German Minority (GM), parents work in Germany, family in Germany and using German language at home. The purpose was to find possible correlates of German national identity.

In the next - sixth - task I asked students about elements which are decision factors as to the belonging of an individual to a given nation. I wanted to know whether and how they understood being a Pole, German, etc.

\section{Results}

Pole scale $(\mathrm{n}=71)$ : most students $(62 \%, 44$ persons $)$ declare that they are definitely Poles. Average in this group equals $3 \mathrm{~mm}$, while average of all respondents is $23 \mathrm{~mm}$. There are only 6 students $(8 \%)$ who define themselves as "not-Pole".

German scale $(\mathrm{n}=71): 48$ students $(69 \%)$ describe themselves as "not-Germans", 3 students - definitely as Germans. The average equals $81 \mathrm{~mm}$. The German identity correlates with parents belonging to the German Minority $(\mathrm{r}=0.47, \mathrm{p}<0.05)-$ in the group of students whose parents are not in GM the average at the German identification scale was $92 \mathrm{~mm}$, in the group of students with both parents in GM average equals $54 \mathrm{~mm}$.

Silesian scale ( $\mathrm{n}=71): 25$ students $(35 \%)$ define themselves definitely as Silesians. At the same time 28 of their peers (39\%) state that they are "not-Silesians". The average equals $52 \mathrm{~mm}$. The Silesian identity correlates with parents belonging to GM ( $\mathrm{r}=0.46, \mathrm{p}<0.05)$. It is higher in a group of students with both parents in GM - average $17 \mathrm{~mm}$, than in a group where only one parent was in GM - average $39 \mathrm{~mm}$ and it is much higher than of those whose parents are not in GM - average $66 \mathrm{~mm}$. It is similar to parents work in Germany, although the correlation is much weaker: $\mathrm{r}=-0.25, \mathrm{p}<0.05$. 


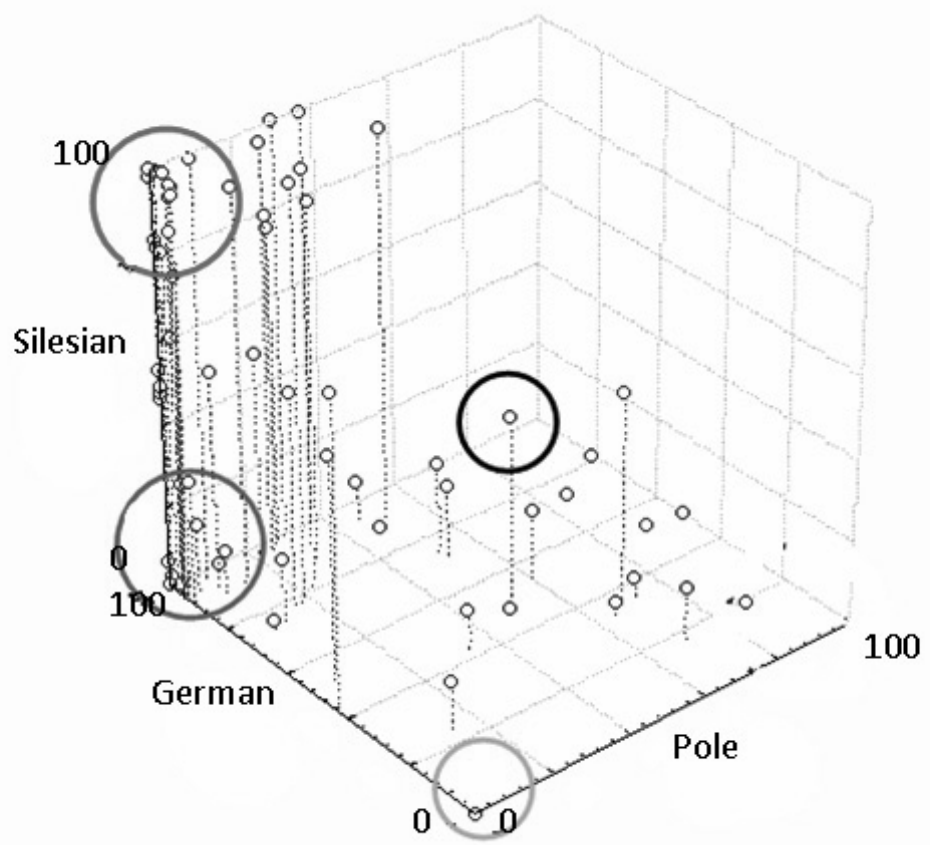

Source: Author

There were 6 students who defined themselves as Poles "for $0 \mathrm{~mm}$ ", at German and Silesian identity scales have chosen totally opposite poles $-100 \mathrm{~mm}$ (in the red circle in the graph). One person pointed " $0 \mathrm{~mm}$ " at every scale, so defines himself as Pole, German and Silesian simultaneously (the yellow circle). Others described themselves by different combinations of two or three identities, usually with dominating Polish. In the green circle are people who defined themselves as definitely Poles and Silesians but "not-Germans". One person (the black circle) pointed around middle at all three scales (respectively 49, 48, $47 \mathrm{~mm}$ ).

Distance: As I mentioned, I widened the scale proposed by B. Weigl by the option of giving a German peer a place in respondents section, which was used by 5 of them and by a possibility of throwing him out of the campsite, which 3 students did. The majority, 31 people (41\%) accommodated him in the very next section and $17 \%$ in the next but one. $15 \%$ lodged him in the remotest section on the site.

Students who have one or both parents in the the German Minority accommodate the German mate closer to their places than respondents whose parents do not belong to the 
German Minority $(\mathrm{r}=0.26, \mathrm{p}=0.05)$. Distance was connected with frequency of speaking German at home. People who never use German at home set average distance at $3.8(\mathrm{n}=30)$. Students from families where German is spoken only when German relatives arrive, set their mate closer, at the average distance of 2.18. Respondents who sometimes speak German at home, gave him place at average distance of $1.42(\mathrm{n}=24)$. Four students in whose homes German is often used accommodated the mate in average distance 1.

Fig. 2 Distance. Triangle represents respondent' tent

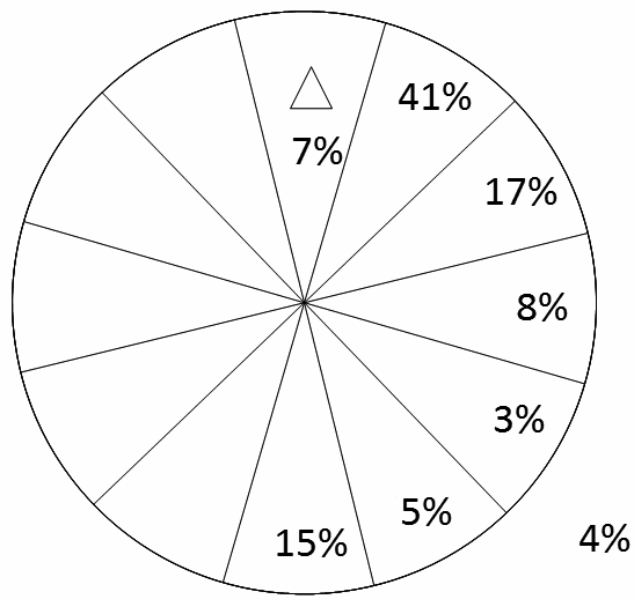

Source: Author

In this context it is interesting what - according to the youths - determinants belonging to given nation. I enumerate answers in groups beginning with most popular:

- place of birth, origin, family origin,

- language,

- culture,

- customs, traditions,

- sense of nationality,

- connections with country, feeling toward country, region, citizenship, relation to nation,

- upbringing, views, agreement,

- behaviour, character,

- surrounding people,

- place of upbringing,

- clothing. 
Note, that the mentioned answers according to academics are components of ethnic identity rather than national. It allows us to treat both of these categories as variants of a sense of group membership.

Students in general more willingly ascribe positive features to Poles and negative to Germans. Exceptions were attributes of responsibility and elegance, which were ascribed to Germans to a greater degree, but were not statistically significant. They regard the "standard Pole" as someone more altruistic and cordial than the "standard German" in social life. Considering mental functioning they found Poles more curious, fit and inventive. They also think that Germans are less brave and self-confident than Poles.

Students who regard themselves as "definitely Pole" $(n=44)$ had a decisively better idea of their compatriots than of Germans in every dimension of performance. It portrays an image of a German as cold- hearted, aloof and a bit of a scoundrel (unreliable, stingy, mistrusting) boastful, rather repugnant in comparison to Poles in the social sphere. They are more often evaluated as cowardly and reckless. In mental aspects they found average Germans as less ambitious, bored, clumsy, obtuse and scatter- brained. Germans were ascribed as having higher irresponsibility, lack of energy, laziness and as without skills. Probably not characteristic of someone with whom they would eagerly meet or cooperate.

Students who defined themselves as being at the extremity $80-100 \mathrm{~mm}$ of the scale "Silesian" have similarly negative views of Germans.

For students who described themselves as "definitely Silesians" $(n=25)$ Poles do not differ dramatically from Germans. The results show up three traits for which difference between averages were significant. "Silesians" consider standard Poles as less active, less elegant and more absent- minded than standard Germans.

I did not make an analysis of stereotypes possessed by "definite Germans" due to the low number in the group.

\section{Summary}

When I started my work on these researches my father showed me an article "Warsaw knows better- there are no Silesians". The title fascinated me much more than content. It is true that on the political map of Europe between the Federal Republic of Germany and Republic of Poland there is nothing we could call Silesia. And there is absolutely no reason why there should be. People live, settle, think and feel independently from political divisions and administrative guidelines. As I wrote in the introduction, the Opole Region is a specific 
region. In 1998 among arguments stated for creating a separate voivodship (instead of incorporation into Silesian or Lower Silesian) there were voices that said that the Opole Region possessed a special climate of tolerance where live Poles, Czechs and Germans, Catholics, Protestants, Kresowiaks and autochthones... It seems that little is needed to embody separation - it is enough to say "We", "They", "our land" and "their language". But within these boundaries we cannot make a geographical space: we cannot say that this village is Polish and that is German, that in this house lives a Polish family and in that German and in another Silesian. Studies of D. Berlińska and my own point out that sometimes this border goes somewhere inside the human, who is simultaneously Pole, German and Silesian.

Most of students admit to having relatives in Germany, parents of the majority work or have worked in that country. Then there comes out a question whether it is connected with such negative image of Germans in youth eyes and above all how does it influence both groups everyday life. Obviously it could be that those two national categories have no meaning as artificial constructs. However, such choices which favour one team or which support one flag are demonstrations of national belonging. That is why student comments such as: "Germans are useless" versus "Deutschland über alles" are disturbing. Admittedly they are justifiable in the light of Z. Bauman's conception which tells us about a need to differentiate and exalt one's group. Nevertheless, that they are justifiable or even natural does not mean that such attitudes are obligatory. History shows that to claim someone's inferiority is one of the first steps of his dehumanization.

\section{Bibliography}

Bauman Z. (1996), Socjologia, Zysk i S-ka, Poznań.

Berlińska D. (1999), Mniejszość niemiecka na Ślqsku Opolskim w poszukiwaniu tożsamości, Instytut Śląski, Opole.

Gauss K.M. (2008), Europejski alfabet, Wydawnictwo Czarne, Wołowiec.

Weigl B. (1999), Stereotypy $i$ uprzedzenia etniczne $u$ dzieci $i$ młodzieży, Wydawnictwo Instytutu Psychologii PAN, Warszawa.

Wojciszke B. (2002), Człowiek wśród ludzi. Zarys psychologii społecznej, Wydawnictwo Naukowe Scholar, Warszawa. 


\section{Netography}

Chandra K. (2005), What is ethnic identity and does it matter?, http://www.nyu.edu/gsas/dept/politics/faculty/chandra/ars2005.pdf, retrieved: 06.06.2009. Kedourie E. (1985), Nationalism, http://books.google.com/books?id=kloVAAAAIAAJ\&printsec=frontcover\&hl=pl, retrieved: 05.06.2009.

Sala S. (2005), Procesy globalizacji ich konsekwencje dla regionów, http://www.paek.ukw.edu.pl/wydaw/vol12/sala2005.pdf, retrieved: 05.06.2009. Scheuerman W. (2008), Globalization, [in:] Zalta E.N. (ed.), The Stanford Encyclopedia of Philosophy (Fall 2008 Edition), http://plato.stanford.edu/archives/fall2008/entries/globalization/, retrieved: 06.06.2009. Smith A. (1993), National identity, http://books.google.com/books?id=bEAJbHBlXR8C\&printsec=frontcover\&hl=pl, retrieved: 06.06.2009. 